Technical Problems.

The tropical crops which chiefly claimed the attention of the congress were rubber and cotton, one day being devoted wholly to the former and one and a half days to the latter. A good deal of discussion took place with regard to the alleged variation in the properties and quality of plantation Para rubber. The discussion made it clear that at present each manufacturer seems to have set up for himself an empirical standard of quality for plantation rubber, and that it is very desirable that some generally accepted standard should be adopted. A number of papers on the cultivation of Ceara, Castilloa, and other rubber-yielding species in various countries were also read, and Messrs. Petch and Green contributed interesting and useful papers on the tapping of Hevea and on the insect pests of Hevea respectively.

A series of papers on cotton was read dealing with almost every phase of this important subject, such as the breeding of new cottons, the selection of cottonseed, the technical qualities which manufacturers require in new cottons, the methods of investigating cottons, and so on. One of the most interesting contributions on cotton was that by Lord Kitchener describing the successful reclamation of a large area of salt land in the Egyptian delta and its utilisation for cotton growing. Equally useful was the address delivered by Mr. Harcourt, Secretary of State for the Colonies, describing the work of the Imperial Institute, the British Cotton Growing Association, the Colonial Departments of Agriculture and other bodies, which under the direct control of the Colonial Office, or with its active sympathy and support, now further in every possible way the cultivation of cotton within the Empire.

The various subjects alluded to above occupy such an important place in every tropical country that a large proportion of the time of the congress was devoted to them, but time was also found for the discussion of a number of subjects which are of special importance to certain countries. Thus Prof. Carmody, of Trinidad, contributed a most interesting account of the experiments on cocoa cultivation and preparation now in progress in that island, and useful contributions on this subject were also made by Messrs. Johnson, Tudhope, van Hall, Booth and Knapp, and others.

Wheat is as yet scarcely regarded as a tropical crop, and Mr. A. E. Humphries's paper on the possibilities of wheat production in the tropics, no less than that of M. Baillaud on the wheats of Tunis and Algeria, was a revelation to many members of the congress of new and unsuspected areas suitable for wheat cultivation.

Herr. Hupfeld's paper on the oil palm in the German colonies was another contribution of which special mention may be made, since it gave an authentic account of the actual operation of European machinery in West Africa in the extraction of palm oil, an innovation which is likely to revolutionise this immense industry, which has hitherto been conducted by natives using most primitive and wasteful methods.

In conclusion mention may be made of the hospitality extended to the members and delegates. H.M. Government gave a dinner to the foreign delegates and a reception for all the members and delegates on the evening of June 23. Both these functions took place at the Imperial Institute. On Saturday, June 27 , a selected party of members and delegates was invited by the Duke of Bedford to visit the Woburn Experimental Farm, and by the Lawes Agricultural Trust to visit Rothamsted. The party exhibited great interest in the experiments in progress at both stations, which were explained to them by $\mathrm{Mr}$. S. U. Pickering and Dr. Russell. A party also visited Kew on the same day on the invitation of Sir David Prain. During the week receptions were held by the Royal Geographical Society, the Royal Colonial Institute, and the Rubber Growers' Association, all of which were largely attended by members and delegates of the congress.

\section{INTERNATIONAL COMMISSION FOR SCIENTIFIC RADIO-TELEGRAPHIC RESEARCHES.}

THE idea of forming an International Commission for the scientific study of questions relating to wireless telegraphy arose from a conversation between Prof. Schmidt and Mr. Goldschmidt, at the International Time Conference in Paris in I912. Representatives from various countries held a meeting in Brussels in October, 1913 , at which a provisional committee was appointed and the general lines of the scheme for the organisation of the working were drawn up. It was decided to send out from the highpower station at Laeken, near Brussels, radiotelegraphic emissions at regular intervals, and that these emissions should be observed and measured by experimenters in Belgium and in other countries.

The commission held a sitting on April 6 at Brussels, under the presidency of $\mathrm{Mr}$. Duddell, at which the commission was constituted definitely. The results already obtained were discussed and arrangements made for future experiments.

National committees, which formed part of the organisation of the International Commission, have been constituted in Belgium, France, and Great Britain. In Germany, many stations have agreed to receive the signals, and a more complete organisation will be formed soon. National committees are also in course of formation in Austria, Russia, Italy, Switzerland, etc.

At the last meeting it was decided to cooperate so far as possible with the work of the Committee for Radio-telegraphic Investigation of the British Association, and the scope of the work was set out.

A demonstration of the methods of emission and measurement in use at the high-power station at Laeken, Brussels, took place before the commission, and reports were read on changes that had been made and on future alterations. The improvements consisted mainly in the use of a new spark-gap having a great damping, and in increasing the extent of the antenna and of the amount of energy radiated.

Arguing from a comparison of the signals received from Brussels, Norddeich, and Paris, Prof. Wien pointed out that there appeared to be difficulties with the present spark circuit, and he expressed the wish that tests should be made with the continuous-wave system. The commission decided that a small highfrequency alternator should be acquired, considering that larger machines are not developed sufficiently yet to warrant the expense.

Reports were read on the photographic registration of signals and other subjects. The reports led to a discussion on the strength of the signals received at the various receiving stations, and the commission expressed the wish that the experimenters should send in, with the results of their experiments, the characteristics of their antenna, and that, whenever possible, they should employ photographic registration.

Mr. Duddell read a paper with regard to the methods and instruments to be employed at the different stations, and other communications were dealt with. 
The officers of the commission, provisionally elected at the first meeting, were confirmed as follows :President, Mr. Duddell; vice-president, Mr. Wien; general secretary, Mr. Goldschmidt; assistant secretary, Mr. R. Braillard.

\section{THE RESEARCH DEFENCE SOCIETY.}

$T \mathrm{HE}$ annual general meeting of the Research Defence Society was held last week at the Royal Society of Medicine. About 160 persons were present, among them Sir William Osler, Sir John Tweedy, Sir David Ferrier, Prof. Cushny, Sir James Reid, Sir Charles Dalrympie, Sir John Brunner, Sir Hugh Bell, and Sir Francis Champneys. Expressions of regret for non-attendance were received from Mr. Waldorf Astor, Mr. Arthur Balfour, Lord Bath, the Dean of Canterbury, Lord Hugh Cecil, Lord Cromer, Sir Francis Darwin, Lord Faber, Lord Farrer, Bishop Frodsham, Mr. Walter Guinness, Lord Claud Hamilton, Sir John Prescott Hewett, Lord Kilmorey, Sir Norman Lockyer, Mr. Walter Long, Prof. Howard Marsh, Lord Northbrook, Sir Gilbert Parker, Sir Frederick Pollock, Sir William Ramsay, Lord Rayleigh, Sir Henry Roscoe, Lord Salisbury, Lord Sheffield, Sir Edgar Speyer, the Bishop of Stepney, Sir Frederick Treves, and Mr. Henry S. Wellcome. The chair was taken by the president, Lord Lamington.

Lord Knutsford, chairman of committee, presented the reports of the society. He referred to the Dogs Protection Bill, pointing out that such a Bill might have prevented the discovery of a cure for distemper; and he directed attention to the educational work of the society. "We are trying, trying, to make the truth understood."

The president then gave his address. After a reference to his predecessors in office, Lord Cromer and the late Sir David Gill, "Our society," he said, "is really a protecting guard for science, in its noblest form, against those who, whilst we can respect their feelings and desires, are led by their emotions rather than by their reason." We should look around, to see what other nations were doing. All nations were engaged in research involving experiments on animals, and that, in most instances, without any legal restriction. "That is a system of which I am sure this country would not approve. Our desire is to reduce human and animal suffering, and on no account to encourage any practice which could possibly tend to permit callousness or indifference to the pain suffered by others. I cannot help thinking that it is this idea which is at the back of the mind of anti-vivisectionists : it is the dislike of seeing human beings engaged in any undertaking involving pain, and the fear of its thereby hardening or debasing human character. It is not merely the fact of pain being inflicted upon the animal, but the fear of the reactive effect on the mind of the person who inflicts the pain. For instance, we should term a farmer, who chose a pet lamb to be killed, rather than one out of his flock, a man of brutal character; yet the pain to the animal would be alike in either case."

Speaking of pain in the animal world, "I may be wrong," he said, "but I am honestly convinced that it is not physical pain that causes the greatest amount of suffering to animals; it is when their instinct of self-preservation takes alarm that they suffer. Anyone who has seen wounded wild animals must have noticed how, when unalarmed, they appear indifferent to their wounds. It is only when their instinct of selfpreservation is aroused, and they become aware of their disablement, that they seem to suffer. . . .

"I wish here to say, most emphatically, that the chief business of our society is not mere fighting. It is the quiet, steady educating of public opinion as to the true character and method of experiments on animals in this country, and the great advantages which these experiments give, not only to human life, but to the life and health of the higher domestic animals."

A vote of thanks was proposed by Sir Reginald Talbot, seconded by Dr. Sandwith. After the meeting, there was a demonstration with the kinematograph of living germs of cholera, typhoid, sleeping sickness, etc.

\section{THE SYNTHETIC POWER OF PROTOPLASM. 1}

$\mathrm{F}$ ROM the point of view of the biological chemist the phenomena of life are manifestations of interactions of colloidal and crystalline materials in a peculiarly organised solution; over and above this every form of protoplasm, existent in any organism, is stereochemically ordered in specific relationship to that organism, so that the products of synthesis have an impressed structure and manifest optical activity. It has been suggested by Prof. Armstrong that the protoplasmic complex may be regarded as built up of a series of associated templates which serve as patterns against which change takes place in the various directions necessary for the maintenance of vital processes. This view is based on the well-known relationship between an enzyme and its hydrolyte; the synthetic enzymes, it may be supposed, serve as patterns for the elaboration of complex materials of definite pattern from the simple units.

In speculating on the origin of organic life from inorganic material Prof. B. Moore has ignored this stereochemical aspect of the question. His use of the well-known synthesis of formaldehyde from carbon dioxide and water in presence of an inorganic catalyst -in his case a colloid-can lead only to optically inactive material, and there is no justification even for the mention of the term life until evidence of directed synthesis is adduced.

The stereochemical hypothesis enunciated has been advocated bv Prof. Reichert, of Pennsylvania, in his researches on hæmoglobin, in which he showed that this substance is modified in specific relationship to genus and species. He now extends the hypothesis to the study of starch, expecting that the peculiarities of the protoplasm in different species of plants will occasion the formation of different types of starch. The variations in the starch granule with origin are, of course, well known, and they are of industrial importance. They are now shown to be absolutely diagnostic in relation to the plant and to constitute a strictly scientific basis for the classification of plants. In addition to recording the microscopic characters of the starches an attempt has been made on a large scale to characterise them chemically, and although these tests are admittedly crude and leave much to be desired, they do mark a great advance in the treatment of the subject.

It may be regarded as established that starches of different origin vary both visibly and in chemical properties; moreover, plants of closely allied species contain starches with similar properties, and it is logical that such variations must be attributed to the differences of protoplasmic influence under which the starch granules are formed. It must not be overlooked, however, that starch granules are made up of three kinds of substances, namely, the true

1 "The Differentiation and Specificity of Starches in Relation to Genera Species, etc." Stereochemistry Applied to Protoplasmic Processes and Products. and as a Strictly Scientific Basis for the Classification of Plants and Animals. By Prof. F. 1. Reichert. In two parts. Pp. xvii $+900+102$ plates. (Washington, D.C.: Carnegie Institution of Washington, I9:3) NO. 2332 , VOL. 93] 